\title{
Pendidikan Politik bagi Anak melalui Organisasi Siswa Madrasah Ibtidaiyah
}

\author{
Nur Shofia Hindun ${ }^{1 *}$, Inayatul Ulya ${ }^{2}$, M. Sofyan Alnashr ${ }^{3}$ \\ ${ }^{1}$ MI Roudlotul Athfal Mutih Kulon \\ 2 3Institut Pesantren Mathali'ul Falah Pati \\ *Email korespondensi: sofiahindun@gmail.com
}

\begin{abstract}
Political education for children is a very good provision in shaping the character of children who are responsible. This study aims to describe how the implementation of political education for students at MI Thowalib Pesagen Pati. This research is a qualitative research with a descriptive approach to describe political education for students through the organization of the Madrasah Ibtidaiyah Student Association (ISMI). The results showed that the background for the formation of ISMI was the ideals of the institution to shape the character of students. Political education for students is carried out through various extracurricular activities such as yasinan, tahlilan, compensation, mutual cooperation, commemoration of Islamic holidays, election of the chairman of ISMI, and other social activities. ISMI is able to make its administrators have a character of responsibility, social care, and democratic.
\end{abstract}

Keyword: political education, political education for children, ISMI

\section{Abstrak}

Pendidikan politik bagi anak menjadi bekal yang sangat baik dalam membentuk karakter anak yang bertanggung jawab. Penelitian ini bertujuan mendiskripsikan bagaimana implementasi pendidikan politik bagi siswa di MI Thowalib Pesagen Pati. Penelitian ini merupakan penelitian kualitatif dengan pendekatan diskriptif untuk menggambarkan pendidikan politik bagi siswa melalui organisasi Ikatan Siswa Madrasah Ibtidaiyah (ISMI). Hasil penelitian menunjukkan bahwa latar belakang dibentuknya ISMI ialah cita-cita lembaga untuk membentuk karakter siswa. Pendidikan politik bagi siswa dilakukan melalui berbagai kegiatan ekstrakurikuler seperti yasinan, tahlilan, santunan, gotong royong, peringatan hari besar Islam, pemilihan ketua ISMI, dan kegiatan sosial lainnya. ISMI mampu menjadikan para pengurusnya memiliki karakter tanggung jawab, peduli sosial, dan demokratis.

Kata kunci: pendidikan politik, pendidikan politik anak, ISMI 


\section{A. Latar Belakang}

Politik diartikan sebagai proses interaksi antar individu demi tercapainya sebuah kebaikan dan kesejahteraan dalam hidupnya (Basri, 2011). Namun kondisi politik di Indonesia saat ini mengalami permasalahan. Realitanya emosi pertarungan elit politik untuk menjadi penguasa telah menjalar kepada masyarakat. Masyarakat yang telah tenggelam dalam pilihan politiknya, bisa memecah belahkan suatu kelompok kecilpun seperti keluarga. BBC News Indonesia (News, 2019) menyebutkan pada tahun 2009 tingkat perceraian dengan persoalan politik mencapai 402 kasus. Tahun 2011 capai 650 kasus, dan mengalami peningkatan pada tahun 2015, angkanya mencapai 21.193 dengan dilatarbelakangi persoalan politik.

Generasi muda dianggap sebagai masyarakat yang paling tidak peduli dalam hal politik dan dianggap tidak berminat pada proses politik serta persoalan politik (Hidayat, 2018). Sementara saat ini para politisi yang ingin maju menjadi anggota dewan menganggap generasi muda yang idealis adalah sasaran empuk untuk dipengaruhi mengenai keberpihakan. Peran generasi muda sebagai pemilih memiliki sumbangsih yang cukup besar terhadap hasil pemilihan. Selain menjadi incaran bagi para politisi, mereka diharapkan menggunakan hak pilihnya dalam pemilu. Memberikan suara saat pemilu merupakan bentuk partisipasi politik. Namun, partisipasi politik bukan hanya sekedar memberi suara saat pemilu saja melainkan ada banyak bentuk partisipasi politik, seperti menjadi anggota partai politik, ikut turun aksi protes, menjadi anggota organisasi kemasyarakatan, menyalonkan diri sebagai politisi.

Posisi dan peran pemuda sangat vital dalam kehidupan kebangsaan sebagaimana termuat dalam Undang-Undang No. 40 Tahun 2009 tentang kepemudaan yang berbunyi "pemuda berperan aktif sebagai kekuatan moral, kontrol sosial, dan agen perubahan dalam segala aspek pembangunan nasional" (RI, 2009). Karena itu generasi muda diharapkan melek politik, menjadi partisipan yang bertanggung jawab dan memahami proses penggunaan kekuasaan menegakkan aturan dalam bermasyarakat serta penggunaan hak politiknya. 
Selain harapan para anak bangsa melek politik diharapkan juga para generasi muda terbentuk jiwa khoirul ummah serta menyadari bahwa di dunia politik dituntut untuk mempertanggungjawabkan amanah yang diemban baik secara politik maupun publik (Mutia et al., 2015). Namun kesadaran politik yang dimiliki setiap individu tidak datang dengan sendirinya melainkan melalui proses yang panjang. Walaupun peran media massa, keluarga, dan pengalaman politik turut menentukan proses pembentukan kesadaran politik seseorang, namun peran lembaga pendidikan pun tidak bisa dikesampingkan.

Untuk mencapai tingkat kesadaran hak dan kewajiban berpolitik bagi setiap individu dibutuhkan sebuah pendidikan yang menransfer mengenai politik baik secara formal maupun non formal. Pendidikan politik sangat penting karena berfungsi meningkatkan keasadaran hak dan kewajiban masyarakat dalam kehidupan bermasyarakat, berbangsa, dan bernegara, meningkatkan partisipasi politik dan inisiatif masyarakat dalam kehidupan bermasyarakat, berbangsa, dan bernegara, serta meningkatkan kemandirian, kedewasaan dan membangun kesatuan dan persatuan negara (RI, 2008). Melalui kegiatan pendidikan politik diharapkan dapat memberikan pengertian yang mendalam terhadap dasar negara dan pandangan hidup bangsa, sejarah, cita-cita, dan tujuan nasional, sehingga menumbuhkan kesadaran berbangsa, bernegara dan cinta tanah air, rela berkorban dan melaksanakan hak dan kewajiban secara seimbang yang dilandasi dengan rasa tanggung jawab (Santoso, 2014).

Pendidikan politik telah diusahakan secara terencana, sistematis, dan terprogram melalui pendidikan formal di sekolah salah satunya termuat dalam materi Pendidikan Kewarganegaraan, yang mana diajarkan di bangku sekolah dasar hingga perguruan tinggi. Hal tersebut menunjukkan bahwa pendidikan politik penting untuk dikenalkan sejak usia dini karena lewat pendidikan politik anak diajarkan memahami atas kekuasaan dan bertanggung jawab atas yang dikuasainya.

Adapun pembelajaran pendidikan politik secara non formal bisa dilakukan diantaranya melalui ekstrakurikuler dan organisasi siswa di sekolah. Khususnya dalam organisasi, siswa memiliki wadah untuk belajar mengenai kepemimpinan, berlatih dalam menyampaikan pendapat, berkomunikasi dengan pihak yang 
berbeda pandangan, berusaha dalam mencapai tujuan sebuah organisasi serta bagaimana cara menjalankan roda organisasi (Fajar, 2014). Tidak hanya itu saja, dengan organisasi di sekolah siswa dilatih agar terlibat dalam demokrasi yang ada di lingkungan sekolahnya, dengan harapan partisispasi di lingkungan sekolah tersebut dapat berkembang di lingkup besar kedepannya.

Pendidikan politik dalam organisasi bertujuan agar siswa memiliki kemampuan berfikir secara kritis, rasional, kreatif, berpartisipasi aktif, sebagai pemacu tumbuhnya rasa keinginan siswa, menumbuhkan semangat dalam berbuat, pendorong dalam mencapai tujuan secara bersama dan dapat menjalankan tugas dengan penuh rasa tanggung jawab. Tujuan yang lainnya (Mutia et al., 2015) ialah agar siswa dapat bertindak secara cerdas dalam kegiatan bermasyarakat, anti-korupsi dan yang paling penting ialah membentuk karakter siswa yang baik, santun dan amanah.

MI Thowalib Pesagen Pati merupakan salah satu madrasah yang menyediakan beberapa wadah untuk mengembangkan bakat dan minat siswa sekaligus mengembangkan aspek kognitif, afektif maupun psikomotorik siswa, diantaranya terdapat keorganisasian siswa, ekstrakurikuler pramuka, drumband, dan rebana, selain itu dengan pembiasaan pembacaan berzanji, tahlil dan upacara bendera setiap hari Senin. Dalam bidang akademik, MI Thowalib Pesagen Pati mengantarkan siswa-siswanya menjuarai perlombaan baik dari tingkat kecamatan maupun tingkat kabupaten. MI Thowalib Pesagen Pati merupakan madrasah yang memiliki keunggulan dalam pendidikan, terbukti menyandang akreditasi A dengan nilai 95 dan menempati posisi 6 di provinsi Jawa Tengah.

MI Thowalib Pesagen memiliki ISMI sebagai salah satu jalan pendidikan politik bagi siswa. Madrasah yang berada di wilayah Gunungwungkal Pati ini membentuk Ikatan Siswa Madrasah Ibtidaiyah (ISMI) untuk mewadahi berbagai macam kegiatan ekstrakurikuler berkaitan dengan bakat, minat, dan sosial. Beberapa kegiatan dari ISMI sejalan dengan pendidikan politik dimana anak dididik supaya terbentuk karakter peduli dan bertanggung jawab.

Pendidikan politik bukan hanya penggabungan dari dua kata yang berbeda yakni antara kata pendidikan dan politik belaka, namun dibaliknya memiliki 
makna yang luas. Pendidikan politik diarahkan sebagai usaha pembinaan potensi tiap individu dalam mengaktualisasikan bakat maupun kemampuannya dan mengembangkan sosialnya sebagai warga negara, sehingga pribadi tiap individu dapat lebih antusias dan kreatif demi bangsa dan negeri.

Pendidikan politik ialah syarat mutlak (condition quo non), sebab di dalamnya mendidik kesadaran rakyat dalam berbangsa dan bernegara (Pasaribu, 2017). Dalam pendidikan politik ini warga negara mengenal dan mempelajari norma-norma, nilai-nilai dan simbol-simbol politik negara dari berbagai pihak dalam suatu sistem politik seperti sekolah, partai politik, dan pemerintah (Surbakti, 2007). Demikian pendidikan politik menjembatani masyarakat dalam meningkatkan wawasan politiknya dan dengan harapan rakyat dapat berpartisipasi secara maksimal dalam sistem politik negara, selaras dengan kedaulatan rakyat yang harus menjalankan tugas partisipasi.

Holdar dan Zakharchenko menyamakan pendidikan politik dengan pendidikan publik (public education). Public education (Holdar \& Zakharchenko, 2002) is effort to involve people in one group and form a culture of participation. Demikian adanya pendidikan politik sebagai pembentukan atau pendidikan diri sendiri, dengan maksud aktivitas dalam membentuk pribadi secara sadar dan penuh tanggung jawab dalam menjadi manusia politik.

Keuntungan secara demografis saat ini mayoritas berasal dari anak muda, dan seringnya anak muda menunjukkan kemauan untuk terlibat dalam pembuatan kebijakan, dan itu perlu diberdayakan melalui pengetahuan. Mereka harus memiliki pengetahuan tentang apa yang diperlukan untuk membangun sebuah masyarakat yang demokratis, dan semua itu terkandung dalam pendidikan politik.

Faktor penting yang mempengaruhi terbentuknya sikap politik para warga negara guna mendukung fungsinya sistem pemerintahan yang baik ialah sebuah pendidikan politik. Urgensinya pendidikan politik disampaikan sejak dini agar tiap individu melek politik. Adapaun landasan pokok yang digunakan dalam pendidikan politik di Indonesia yakni Pancasila, UUD 1945, dan sumpah pemuda 1928 (Handoyo \& Lestari, 2017). 
Tujuan pendidikan politik yakni supaya para siswa memiliki keahlian berfikir secara kritis, kreatif, dan logis dalam merespon isu kewarganegaraan, berkonstribusi aktif serta bertanggung jawab, dan berlaku secara cermat dalam kegiatan bermasyarakat, bernegara, dan berbangsa (Haryanti, 2016). Pendidikan politik (Sanusi \& Darmawan, 2016)mampu memberikan pemahaman politik bagi para kader untuk berpikir dan berperilaku berdasar pada pengalaman nilainilai Aswaja dan Pancasila.

Sehingga dapat ditarik kesimpulan bahwa pendidikan politik suatu ikhtiar mempelajari tentang norma-norma, lambang negara, lambang politik dan berupaya secara sadar melatih diri dalam mengembangkan potensi yang dimiliki agar menjadi pribadi yang aktif, kreatif demi bangsa dan negeri, selain itu juga dan diamalkan dengan penuh rasa tanggung jawab dengan tujuan agar tecapainya suatu kehidupan yang baik antar warga negara.

\section{B. Metode Penelitian}

Penelitian ini menggunakan pendekatan kualitatif yang menekankan analisis terhadap dinamika antara fenomena yang diamati dengan menggunakan logika ilmiah. Dari segi sifatnya penelitian ini bersifat penelitian deskriptif, artinya penelitian untuk mendeskripsikan dan menggambarkan fenomenafenomena apa adanya tanpa ada campur tangan peneliti (Sukmadinata, 2011). Dalam hal ini peneliti menggambarkan atau mendeskripsikan tantang implementasi pendidikan politik pada siswa MI Thowalib Pesagen Pati.

Sumber-sumber penelitian terdiri dari dua sumber yakni sumber primer (utama) melalui wawancara yang telah disusun untuk mengetahui implementasi pendidikan politik melalui ISMI di MI Thowalib Pesagen. Kemudian diperkuat dengan sumber sekunder (sumber pendukung) dari observasi dan dokumen terkait dengan implementasi pendidikan politik pada organisasi ISMI di MI Thowalib Pesagen Pati. Analisis interaktif (Miles et al., 2014) digunakan untuk menjelaskan penelitian ini meliputi pengumpulan data, reduksi data, penyajian data, dan penarikan kesimpulan. 


\section{Hasil dan Pembahasan}

1. Latar belakang terbentuknya organisasi siswa ISMI di MI Thowalib Pesagen Pati

Setiap lembaga sekolah memberikan pembinaan kepada para siswa. Salah satu bentuk pembinaan kesiswaan yaitu berupa organisasi siswa intra sekolah yang tidak berhubungan dengan organisasi siswa di lembaga sekolah lain. MI Thowalib Pesagen mengaplikasikan pembinaan kesiswaan dalam bentuk kegiatan ekstrakurikuler dan organisasi kesiswaan. Orgnisasi tersebut diberi nama Ikatan Siswa Madrasah Ibtidaiyyah atau yang disingkat ISMI. Sebelum bernama ISMI, organisasi siswa MI Thowalib bernama ICMI singkatan dari Ikatan Cendikiawan Madrasah Ibtidaiyyah. Namun, dirasa terlalu tinggi maknanya maka diganti dengan ISMI.

Dalam proses dibentuknya organisasi siswa, beberapa pihak Madrasah Thowalib mempertimbangkan dan memerhatikan Peraturan Menteri Pendidikan Nasional mengenai pembinaan kesiswaan. Berdasarkan Permendiknas tentang Pembinaan Kesiswaan tersebut, MI Thowalib membentuk organisasi siswa intra sekolah dengan nama Ikatan Siswa Madrasah Ibtidaiyyah ( ISMI ).

Dibentuknya organisasi siswa tingkat dasar ini, bertujuan agar para siswa dapat belajar mandiri, berorganisasi serta berlatih kepemimpinan sejak dini mungkin, dengan konsep pembelajaran yang aplikatif, mengingat siswa dalam tingkat sekolah dasar masih dalam taraf belajar secara bermakna atau secara langsung. Selain itu, ISMI dibentuk guna menyiapkan para siswa untuk siap guna di masyarakat (Sundoyo, 2020).

ISMI (Ikatan Siswa Madrasah Ibtidaiyyah) merupakan wadah bagi masyarakat sekolah dalam mencapai tujuan tertentu secara bersama yang sebelumnya tidak dapat dicapai secara perorangan. Organisasi ISMI pun memiliki dampak positif dan manfaat terutama dalam mengembangkan bakat siswa. Seluruh anggota ISMI berkesempatan berpartisipasi dalam kegiatan yang diselenggarakan oleh pengurus ISMI, dan contoh kegiatan yang meningkatkan bakat siswa adalah perlombaan-perlombaan. 
Sedangkan, disisi lain dalam mengembangkan bakat siswa ialah seluruh siswa berkesempatan untuk menjadi pengurus ISMI.

Dalam penempatan pengurus ISMI, siswa ditempatkan dalam bidang yang sesuai dengan karakter, kemampuan dan bakat yang dimiliki siswa. Bakat yang dikembangkan dalam ISMI yakni bakat non-akademik siswa. Dibuktikan dengan seringnya siswa MI Thowalib mendapatkan juara perlombanan dalam bidang non-akademik hingga di tingkat kabupaten Pati. Karena setiap pengurus menjadi publik figur bagi teman-temannya, sehingga harus menjadi teladan baik bagi seluruh siswa dalam kegiatan sehari-hari. Selain itu, setiap pengurus memiliki tugas masing-masing yang harus dilakukan, dengan begitu siswa dilatih untuk bertanggungjawab. Namun, di lapangan masih didapatkan pengurus ISMI yang tidak bertanggunjawab, dibuktikan dengan ketika pelaksanaan kegiatan beberapa pengurus masih saling melempar tugas.

Terdapat perbedaan karakter antara pengurus dan anggota ISMI. Sebagian besar siswa yang menjadi pengurus memiliki karakter yang disiplin, santun, peduli, percaya diri dan semangat dalam melaksanakan kegiatan. Hal tersebut karena tiap pengurus ditekankan oleh pembina agar menjadi publik figur bagi teman lain (Amar, 2020). Sedangkan manfaat ISMI bagi lembaga adalah terbantunya dalam mencapai tujuan madrasah secara umum, yaitu "meletakkan dasar intelektualitas, wawasan, berkarakter, berbudi luhur, serta ketrampilan siswa untuk mencapai kehidupan yang mandiri dan melakukan pendidikan lebih lanjut", meringankan tugas pendidik di MI Thowalib, serta menjadi poin promosi dalam mendapatkan siswa baru (Munafi', 2020).

Berorganisasi mengajarkan antar pribadi siswa secara berkelompok mencapai tujuan bersama yang telah disepakati. Hal tersebut sudah diterapkan di MI Thowalib yakni dengan membentuk organisasi ISMI bagi siswa dan berada di dalam lingkup madrasah serta tidak memiliki keterkaitan dengan organisasi di lembaga lain. Dibentuknya ISMI, bertujuan melatih keorganisasian siswa dan melatih dalam kemandirian siswa guna bekal di masa akan datang. 
Selain itu, latar belakang terbentuknya ISMI madrasah menyimpan harapan bagi para siswa yakni, seluruh siswa MI Thowalib agar siap berguna bagi masyarakat sekitar dan ikut berpatisipasi aktif dalam kegiatankegiatan yang bermanfaat bagi sesama demi kemajuan bangsa dan negara. Hal demikian, selaras dengan fungsi pendidikan politik, yakni sebagai usaha pembinaan potensi tiap individu dalam mengaktualisasikan bakat maupun kemampuannya dan mengembangkan sosialnya sebagai warga negara, sehingga pribadi tiap individu dapat lebih antusias dan kreatif demi bangsa dan negeri (Handoyo \& Lestari, 2017).

\section{Pelaksanaan Pendidikan Politik melalui ISMI di MI Thowalib Pesagen}

Perencanaan pembelajaran merupakan langkah awal dalam menetapkan tujuan yang hendak dicapai, sehingga mewujudkan pembelajaran yang efektif. Pada dasarnya, perencanaan memutuskan proses yang akan dijalankan di masa akan datang. Hal-hal yang direncanakan dalam kegiatan ISMI MI Thowalib diawali dengan penyusunan Anggaran Dasar Rumah Tangga (AD/ART) organisasi ISMI berlandas pada visi, misi, dan tujuan lembaga MI Thowalib Pesagen Pati. AD/ART ISMI mengatur segala bentuk aturan dan prosedur dalam pelaksanaan kegiatan ISMI, serta berisi hak dan tangung jawab baik pembina, pengurus, dan anggota ISMI.

Perencanaan pada penyusunan kegiatan ISMI melibatkan kepala madrasah, pembina ISMI, dan guru di MI Thowalib mengingat organisasi ISMI diisi para siswa yang masih dalam umur anak-anak. Dengan begitu, pihak pendidik MI Thowalib yang menyusun sedangkan para pengurus ISMI tinggal mengeksekusi kegiatan yang telah disusun oleh lembaga. Penyusunan kegiatan ISMI dilakukan setiap tahunnya, yakni pada waktu awal periode kepengurusan yang bertepatan dengan awal tahun pembelajaran.

Seluruh kegiatan ISMI hanya mencakup kegiatan ekstrakurikuler yakni kegiatan yang berkaitan dengan para siswa MI Thowalib Pesagen Pati. Perencanaan kegiatan juga mengacu pada visi, misi, dan tujuan Madrasah Thowalib Pesagen Pati. Adapun visi organsiasi ISMI disamakan dengan visi 
madrasah yakni "Terwujudnya Generasi Islam yang Terampil, Berakhlaq Karimah dan Unggul dalam Berprestasi”. Sehingga semua kegiatan ISMI sepenuhnya mendukung tujuan dari lembaga MI Thowalib Pesagen Pati yakni meningkatkan kemampuan akademik, minat dan bakat siswa melalui layanan bimbingan konseling dan pembinaan kesiswaan.

Setiap organisasi memerlukan peran pengawas sehingga organisasi tersebut dapat berjalan lurus sesuai dengan aturan dan tata tertib. Pengawas dalam organisasi biasanya disebut sebagai pembina organisasi. Penentuan pembina ISMI dipilih secara langsung oleh Kepala Madrasah. Adapun tugas pembina ialah sebagai motivator, pengawas dan kontroling kegiatan ISMI. Jadi, semua kegiatan ISMI di bawah kendali pembina, dan peran pembina dalam membimbing pengurus ISMI lebih insentif, mengingat pengurus ISMI seluruhnya masih anak-anak.

Adanya peran pembina, ruang kreativitas siswa melalui organisasi ISMI tidak menjadi terbatas. Para siswa diberi kebebasan dalam menyatakan pendapatnya dan bermusyawarah bersama setiap akan diadakannya kegiatan. Di sinilah para pengurus dan anggota ISMI belajar demokratis. Ruang kreativitas siswa juga didukung dengan sarana dan prasarana yang disediakan oleh madrasah, yakni berupa lingkungan madrasah yang luas, beberapa ruangan kelas dan ruang kantor, begitu juga diperbolehkannya oleh pihak madrasah kepada ISMI untuk berkegiatan di luar madrasah (Munafi', 2020).

Melalui kegiatan ISMI anak dapat belajar dalam hal berorganisasi dan kepemimpinan secara praktek, tidak hanya teori saja. Jadi, pengaplikasian pembelajaran berorganisasi dalam bentuk kegiatan pada para siswa sesuai dengan kemampuan, minat, bakat dan karakter siswa. Kegiatan ISMI di MI Thowalib berkaitan dengan kegiatan ekstrakurikuler siswa. ISMI mengadakan iuran kas setiap hari sebesar Rp. 100 dan diwajibkan bagi seluruh siswa MI Thowalib. Pelaksanaan iuran tersebut dikoordinasikan antara bendahara ISMI dengan ketua kelas masing-masing. Kas tersebut digunakan untuk membiayai seluruh kegiatan ISMI, jika 
terdapat kekurangan akan dibantu dana dari lembaga. Sehingga siswa dapat mengikuti semua kegiatan tanpa mengeluarkan biaya.

Kegiatan yang dilakukan setiap hari Senin, yakni mengadakan acara tahlilan, yasinan, dan upacara. Kegiatan tersebut bergilir setiap minggunya. Adapun tugas ISMI dalam acara yasinan dan tahlilan adalah menyiapkan tempat dan pemimpin dalam kegiatan tersebut. Adapun pemimpin diambil dari salah satu guru MI Thowalib. Sedangkan dalam upacara bendera hari Senin, pengurus ISMI sebagai petugas upacara.

Kegiatan lain dari ISMI antara lain Peringatan Hari Besar Islam/Nasional (PHBI/PHBN). Kegiatan rutinitas setiap tahun ini melibatkan seluruh masyarakat sekolah. Pengurus ISMI yang menyiapkan segala sesuatu acara tersebut dan berkoordinasi langsung dengan pengurus $\mathrm{PHBI} / \mathrm{PHBN}$ lembaga. Acara PHBI dan PHBN tersebut adalah peringatan Maulid Nabi Muhammad, Isro' Mi'roj, peringatan Hari Kartini, Hari Santri Nasional, Hari Kemerdekaan Indonesia. Adapun program tersebut diisi dengan kegiatan pengajian, sholawatan, upacara peringatan, dan perlombaan lingkup sekolah.

Pemilihan ketua ISMI dikoordinasikan antara panitia pemilihan dengan pembina ISMI. Para siswa diberi kebebasan mendaftarkan diri sebagai calon kandidat ketua ISMI, namun hanya bagi kelas 4 - 6 saja. Untuk yang bisa memilih bagi siswa kelas $3-6$ dengan sistem pemilihan seperti pemilihan umum. Sebelum pemilihan, ada masa kampanye bagi para calon ketua ISMI, yakni para panitia pemilihan menyebarkan foto-foto para kandidat ketua di dalam dan luar lingkungan madrasah. Para siswa juga mendapatkan sosialisasi dari para guru dan pembina, agar para siswa menjadi pemilih yang bijak dan selektif dalam memilih kandidat. Dengan demikian para siswa dapat memilih kandidat yang mumpuni dan tidak akan salah pilih ketua, sekaligus ketua yang terpilih sesuai dengan harapan.

Kegiatan ISMI dalam bentuk lain yakni kegiatan sosial. Kegiatan tersebut berupa menengok siswa MI Thowalib yang sedang sakit. Kegiatan sosial tersebut dilaksanakan dengan menggunakan uang kas ISMI dan dikoordinir langsung oleh pengurus ISMI dengan bimbingan dari pembina. 
Kegiatan tersebut telah diagendakan oleh pembina dan pihak madrasah dan ISMI sebagai pelaksana, namun demikian, secara keseluruhan susunan dan konsep acara dari hasil musyawarah pengurus ISMI dengan arahan dari pembina ISMI.

Pendidikan bertujuan supaya generasi penerus bangsa yakni siswa cakap beradaptasi dengan lingkungan global sekaligus mampu melindungi khazanah nasional dalam menghadapi globalisasi. MI Thowalib telah lama menerapkan pendidikan politik kepada para siswa. Selain mengajarkan pendidikan politik dalam pembelajaran teori-teori di dalam kelas dengan melalui mata pelajaran Pendidikan Kewarganegaraan, MI Thowalib juga mengajarkan mengenai pendidikan politik kepada siswa melalui pembinaan kesiswaan berupa kegiatan dalam organisasi ISMI (Ikatan Siswa Madrasah Ibtidaiyyah).

Pendidikan politik dapat ditransformasikan kepada siswa dalam bentuk pendidikan formal maupun non-formal. Dalam hal demikian, MI Thowalib Pesagen Pati telah lama menerapkan pendidikan politik melalui pembelajaran Pendidikan Kewarganegaraan di dalam kelas dan organisasi ISMI. Kegiatan yang telah dijelaskan di atas menujukkan bahwa organisasi ISMI memiliki peran dalam menyampaikan pendidikan politik dalam lingkup sekolah pada siswa.

ISMI mengajarkan mengenai berpolitik secara sehat, mendidik siswa dalam mematuhi aturan, mengajarkan tentang kewajiban, hak, serta tanggung jawab sebagai warga sekolah. Selaras dengan pendapat Purba bahwa pendidikan politik merupakan proses pemahaman mengenai hak, kewajiban, dan tanggung jawab sebagai warga negara (Purba \& Dkk, 2012).

\section{Kesimpulan}

Berdasarkan hasil penelitian dan pembahasan dapat diambil kesimpulan bahwa latar belakang pembentukan organisasi Ikatan Siswa Madrasah Ibtidaiyyah (ISMI) adalah sebagai ikhtiyar madrasah dalam membantu para siswa mengembangkan bakat serta potensi yang dimiliki, dengan upaya mendidik dan melatih siswa berorganisasi. Serta membekali siswa dengan pengalaman- 
pengalaman guna tidak gagap dalam berorganisasi di masa akan datang. Pelaksanaan kegiatan ISMI di MI Thowalib Pesagen Pati sebagai bentuk pendidikan politik siswa memberikan manfaat besar sehingga madrasah terbantu dalam mencapai tujuan lembaga. ISMI mampu membentuk karakter mandiri, percaya diri, kreatif dan bertanggung jawab bagi anak.

\section{Daftar Pustaka}

Amar. (2020). Wawancara.

Basri, S. (2011). Pengantar Ilmu Politik. Indie Books.

Fajar, W. N. (2014). Pelaksanaan Pendidikan Politik Di Sekolah Dalam Meningkatkan Kesadaran Politik Siswa. Jurnal Khazanah Pendidikan, 6(2). https://doi.org/10.30595/jkp.v6i2.657

Handoyo, E., \& Lestari, P. (2017). Pendidikan Politik. Pohon Cahaya.

Haryanti, A. (2016). Peran dan Sikap Guru dalam Mensosialisasikan Pendidikan Politik di Sekolah. Pekobis: Jurnal Pendidikan, Ekonomi, Dan Bisnis, 1(1). https://doi.org/http://dx.doi.org/10.32493/pekobis.v1i1.P\%25p.351

Hidayat, A. N. (2018). Beda Cara Generasi Milenial dalam Politik. Www.Kompas.Com. https://nasional.kompas.com/read/2018/09/17/19090001/beda-caragenerasi-milenial-dalam-politik?page $=$ all

Holdar, G. G., \& Zakharchenko, O. (2002). Citizen Participation Handbook. iMedia Ltd.

Miles, M. B., Huberman, A. M., \& Saldana, J. (2014). Cross-case data analysis. In Qualitative data analysis: An expanded sourcebook.

Munafi'. (2020). Wawancara.

Mutia, R. A., Widayanti, W., \& Astuti, P. (2015). Peran Sekolah dalam Pendidikan Politik Bagi Siswa di Sekolah Menengah Atas Islam Hidayatullah Semarang. Journal of Political and Goverment Studies, 4(1), 16-25.

News, B. (2019). Rumah tangga retak karena beda pilihan politik? "Jangan mati-matian bela capres." Www.Bbc.Com. https://www.bbc.com/indonesia/indonesia47935315

Pasaribu, P. (2017). Peranan Partai Politik dalam Melaksanakan Pendidikan Politik. JPPUMA: Jurnal Ilmu Pemerintahan Dan Sosial Politik Universitas Medan Area, 5(1). https://doi.org/10.31289/jppuma.v5i1.1125

Purba, B. H., \& Dkk. (2012). Buku Pedoman Pendidikan Politik. Badan Penelitian dan Pengembangan HAM Kementerian Hukum dan HAM Republik Indonesia.

RI, U. (2008). Undang-Undang Nomor 2 Tahun 2008 tentang Partai Politik. 
RI, U. (2009). Undang-Undang Nomor 40 Tahun 2009 tentang Kepemudaan.

Santoso. (2014). Pendidikan Politik terhadap Pemilih Pemula.

Http://Eprints.Umk.Ac.Id/6057/3/Artikel.Pdf.

Sanusi, A. R., \& Darmawan, C. (2016). Implementasi Pendidikan Politik dalam Membentuk Karakter Kepemimpinan Lintas Budaya pada Generasi Muda Demi Mewujudkan Budaya Politik Pancasila. Jurnal Pendidikan Ilmu Sosial, 25(1).

Sukmadinata, N. S. (2011). Metode Penelitian Pendidikan. Remaja Rosdakarya.

Sundoyo. (2020). Wawancara.

Surbakti, R. (2007). Memahami Ilmu Politik. Gramedia Widiasarana Indonesia. 